\title{
Evolution of insecticide resistance in non-target black flies (Diptera: Simuliidae) from Argentina
}

\author{
Cristina Mónica Montagna ${ }^{1 /+}$, Lidia Ester Gauna', Ana Pechen de D’Angelo², Olga Liliana Anguiano² \\ 1Facultad de Ciencias del Ambiente y de la Salud ²Facultad de Ingeniería, Instituto Multidisciplinario \\ de Investigación y Desarrollo de la Patagonia Norte, Universidad Nacional del Comahue, Buenos Aires 1400, (8300) Neuquén, Argentina
}

Black flies, a non-target species of the insecticides used in fruit production, represent a severe medical and veterinary problem. Large increases in the level of resistance to the pyrethroids fenvalerate (more than 355-fold) and deltamethrin (162-fold) and a small increase in resistance to the organophosphate azinphos methyl (2-fold) were observed between 1996-2008 in black fly larvae under insecticide pressure. Eventually, no change or a slight variation in insecticide resistance was followed by a subsequent increase in resistance. The evolution of pesticide resistance in a field population is a complex and stepwise process that is influenced by several factors, the most significant of which is the insecticide selection pressure, such as the dose and frequency of application. The variation in insecticide susceptibility within a black fly population in the productive area may be related to changes in fruit-pest control. The frequency of individuals with esterase activities higher than the maximum value determined in the susceptible population increased consistently over the sampling period. However, the insecticide resistance was not attributed to glutathione S-transferase activity. In conclusion, esterase activity in black flies from the productive area is one mechanism underlying the high levels of resistance to pyrethroids, which have been recently used infrequently. These enzymes may be reselected by currently used pesticides and enhance the resistance to these insecticides.

Key words: black fly - insecticide resistance - fenvalerate - deltamethrin - azinphos methyl

Black flies (Diptera: Simuliidae) are found worldwide, in America from north (Canada) to south (Argentina) as well as in Europe, Africa, Asia, Oceania and Antarctica continents (Crosskey \& Howard 2004, Currie \& Adler 2008). Black flies breed in fast-flowing streams and they are usually pests of medical and veterinary importance, with approximately 2,000 nominal species (Currie \& Adler 2008). Black flies are nuisance insects and some species are fierce biters that cause allergic reactions and dermatitis in sensitised individuals (De Villiers 1987, Williams 1991, Youssefi et al. 2008). Some black flies are also vectors of human diseases in many countries (Hougard et al. 1992, Shelley 2002). They also attack livestock, causing economic losses due to reductions in milk and beef production (Schmidtmann et al. 2001).

Black fly control programmes have primarily been implemented to arrest the transmission of Onchocerca volvulus in Africa and Central and South America through the use of larvicides or adulticides (McMahon 1967). Some of the larvicides have included the organochlorines DDT, $\mathrm{HCH}$ and dieldrin, the organophosphates temephos and chlorphoxim, the carbamate carbosulfan and the pyrethroid permethrin (McMahon 1967, Yamagata et al. 1987, Hougard et al. 1992, Paugy

Financial support: UNCOMA Projects (04/I701, 04/I940, 04/I004), FONCYT (PICT-2007-00214-00-01)

+ Corresponding author: monica.montagna@facias.uncoma.edu.ar Received 24 July 2011

Accepted 14 March 2012 et al. 1999). In addition, biological control with Bacillus thuringiensis var. israelensis has been successfully implemented in Africa (Rivers-Moore et al. 2008), Brazil (Regis et al. 2000) and other countries such as Lithuania, where outbreaks of bloodsucking black flies affect daily human activities (Bartninkaitè et al. 2006). Because of the success of the Onchocerciasis Control Program in West Africa and Central and South America, which utilises both biopesticides against the vector $(B$. thuringiensis) and the parasite (ivermectin) (Etya'ale 2001), there have only been a few reported cases of insecticide resistance in black fly populations that are vectors of $O$. volvulus (Ruas Neto 1984, Hougard et al. 1992).

Three species of black flies have been identified in the Río Negro and Neuquén Valley (Coscarón 1997): Simulium bonaerense (Coscarón and Wygodzinsky), Simulium wolffhuegeli (Enderlein) and Simulium nigristrigatum (Wygodzinsky and Coscarón). All three species are nuisance and biting pests of humans and livestock. These non-target species are found from spring to autumn and their development overlaps with the seasonal pesticide spraying used to control Cydia pomonella (L.) and other fruit tree pests in the Río Negro and Neuquén Valley. C. pomonella has three generations per year and pest control programmes in the previous century have included several applications of broad-spectrum insecticides, principally pyrethroids. During the 1993-1994 growing season, many farmers began to report control failures with pyrethroids, especially esfenvalerate. Subsequently, azinphos methyl was primarily recommended for codling moth management along with other unconventional insecticides. In recent years, although conventional pesticides such as azinphos methyl, carbaryl and pyrethroids are still applied, neonicotinoids (acet- 
amiprid, thiacloprid), rynaxypyr, insect growth regulators (novaluron) and microbial insecticides (spinosad) are the primary choices for many farmers.

Because black fly populations breed successfully in the channel network that was implemented to manage water for fruit production, they are subjected to pesticide residues via spray drift and run-off. Pesticide spraying also reaches adult black flies at their resting sites.

High levels of resistance to DDT and pyrethroids were found in non-target black flies from the Río Negro and Neuquén Valley by the end of the previous century (Montagna et al. 1999, 2003). Other authors have also attributed insecticide resistance in black flies (Andrade \& Branco 1990, Osei-Atweneboana et al. 2001) and mosquito populations (Diabate et al. 2002) to agricultural pesticide use.

The aim of this study was to evaluate the development and mechanisms of fenvalerate, deltamethrin and azinphos methyl resistance in non-target black fly populations from a fruit production area in Northern Patagonia (Argentina) over a period of 13 years.

\section{MATERIALS AND METHODS}

Chemicals - The insecticides fenvalerate $[93.9-97 \%$ active ingredient (AI)], deltamethrin $(96.5-99.8 \%$ AI) and azinphos methyl $(96.5-99 \% \mathrm{AI})$ were purchased from AccuStandard Inc, New Haven, CT, USA and Chemical Service Inc, West Chester, PA, USA. Reduced glutathione, 1-chloro-2,4-dinitrobenzene (CDNB), $\alpha$-naphthyl acetate, $\alpha$-naphthol $(\alpha-\mathrm{N})$, Fast Garnet GBC salt, Triton $\mathrm{X}-100$, bovine serum albumin (BSA) and 1,5-bis(4-allyldimethylammonium phenyl)pentan-3-one dibromide (BW284C5) were purchased from Sigma Chemical Co, St. Louis, MO, USA.

Study area - The insecticide-exposed population was collected from an important irrigation channel at Fernández Oro (FO) $\left(38^{\circ} 16^{\prime} \mathrm{S} 67^{\circ} 45^{\prime} \mathrm{W}\right)$. A population collected upstream at Piedra del Águila (PA) (lat. $42^{\circ} 2^{\prime} \mathrm{S} 70^{\circ} 5^{\prime} \mathrm{W}$ ), which had no history of pesticide application and thus had a more susceptible population, was used as a fieldreference population (Montagna et al. 1999, 2003). Larvae of Simulium spp were collected from the studied areas (from October-early March) and were attached to aquatic weeds, such as Potamogeton pectinatus and Chara vulgaris L., or submerged branches of Salix babylonica L. and transported to the laboratory inside a cool box. The larval sample size was always variable (from approximately 100-600 larvae) and depended on the weather conditions and the available vegetation (vegetation from the channel is periodically removed mechanically).

Toxicity assays - Bioassays were performed immediately after the selection of fifth instars with white histoblasts. The bioassays on field populations of the Simulium larvae were performed according to a previously described procedure (Montagna et al. 1999, 2003). Groups of 20 larvae were exposed to $\geq$ four concentrations (except in those cases in which the larvae exhibited a very homogeneous response) of technical-grade insecticide dissolved in $0.1 \mathrm{~mL}$ acetone in a final volume of $200 \mathrm{~mL}$ filtered dechlorinated water. Each test was replicated at least three times on different days. The larvae were maintained at $15 \pm 1^{\circ} \mathrm{C}$ for $24 \mathrm{~h}$ with a photoperiod of 16:8 (L:D) h. The mortalities of both the treated and control larvae were determined after this treatment.

Enzyme activity - Fifth instar larvae with white histoblasts were selected immediately after the field collection and individually frozen at $-20^{\circ} \mathrm{C}$ for a few days until the enzyme assays were performed. The non-specific esterase activity was determined individually (Dary et al. 1990). The larvae were homogenised with a Teflon homogenisation rod in $100 \mu \mathrm{L} 0.1 \mathrm{M}$ sodium phosphate buffer ( $\mathrm{pH}$ 6.5) containing $0.5 \%$ Triton X-100. Each sample was centrifuged at $700 \mathrm{~g}$ for $20 \mathrm{~s}$ and the supernatant was used as the enzyme source. A $20-\mu \mathrm{L}$ aliquot of the supernatant was diluted into the homogenisation buffer to obtain values within the linear range of the assay. Aliquots of $50 \mu \mathrm{L}$ were loaded in a 96-well ELISA plate incubated on ice. The reaction was initiated in each well by the addition of $100 \mu \mathrm{L}$ developing solution. The developing solution contained distilled water, $0.1 \mathrm{M}$ sodium phosphate buffer ( $\mathrm{pH} 6.5$ ), $0.5 \%$ Triton X-100, final concentration $2 \mathrm{mM} \alpha-\mathrm{NA}$ in ethanol and $0.002 \mathrm{mM}$ BW284C5 in ethanol. The microplate was then removed from the ice and its contents were mixed; esterase hydrolysis was allowed to proceed for $15 \mathrm{~min}$. Next, $100 \mu \mathrm{L} 2.5$ mM Fast Garnet GBC salt was added and the absorbance at $550 \mathrm{~nm}$ was recorded after 10 min with a microplate reader (Molecular Devices, Sunnyvale, CA, USA). The absorbance values were transformed to $\mu$ moles of $\alpha-\mathrm{N}$ according to an $\alpha-\mathrm{N}$ standard curve. Each enzyme preparation was replicated twice.

Glutathione S-transferase (GST) activity towards CDNB (0.5 mM in acetonitrile) was determined with batches of 25 larvae homogenised in $66 \mathrm{mM}$ phosphate buffer containing $25 \mathrm{mM}$ sucrose ( $\mathrm{pH} 7.0$ ) according to the method described by Habig et al. (1974). Each sample was centrifuged at $10,000 \mathrm{~g}$ for $20 \mathrm{~min}$ at $4^{\circ} \mathrm{C}$ and the supernatants were used without further purification. The reaction mixture consisted of $2.77 \mathrm{~mL} 0.1 \mathrm{M}$ phosphate buffer (pH 6.5), $50 \mu \mathrm{L}$ enzyme source, $30 \mu \mathrm{L}$ CDNB and $150 \mu \mathrm{L} 2.5 \mathrm{mM}$ reduced glutathione in a final volume of $3 \mathrm{~mL}$. The absorbance was recorded continuously at $340 \mathrm{~nm}$ for $2 \mathrm{~min}$ with a ultra-violet/visible spectrophotometer (Shimadzu, Kyoto, Japan). The rate measurements were corrected for the non-enzymatic reaction. The absorbance values were transformed to $\mu$ moles of CDNB conjugates with an extinction coefficient of 9.6 $\mathrm{mM}^{-1} \mathrm{~cm}^{-1}$. At least five different enzyme preparations for each population were assayed.

The protein preparations were assayed for esterase or GST activity according to the method of Lowry et al. (1951) individually or as a batch of supernatants from 25 larvae, respectively. The absorbance at $750 \mathrm{~nm}$ was measured and transformed into a protein concentration according to a BSA standard curve.

Statistical analysis - Lethal concentration fifty $\left(\mathrm{LC}_{50}\right)$ values were calculated from a probit analysis as implemented in the BASIC program, St. George d'Orques, France (Raymond 1985). The correction for control mortality, which was always below $10 \%$, was analysed with the same program using Abbot's formulae. The calcu- 
lated $\mathrm{LC}_{50}$ values were considered different if their $95 \%$ confidence intervals (CIs) did not overlap. Because there had been a very low population density of black flies in PA over the past few years, the resistance ratios $\left(\mathrm{LC}_{50}\right.$ of the resistant population/ $\mathrm{LC}_{50}$ of the field-reference population) were calculated with the latest $\mathrm{LC}_{50}$ value recorded for the field-reference population. The mean esterase activities from both the individual resistant and field-reference populations were compared by non-parametric ANOVA (Kruskal Wallis) followed by Dunn's multiple comparison test. The mean GST activities were analysed by two-way ANOVA followed by Fisher's least significant difference test.

\section{RESULTS}

Toxicity assays - The concentration mortality lines for fenvalerate are shown in Fig. 1, together with complementary results from 1997 and 1999 that have been published elsewhere (Montagna et al. 1999, 2003). The FO population mortalities in 2002, 2005 and 2008 were $42 \%$ or less at the highest concentration of fenvalerate assayed $\left(2.5 \mathrm{mg} \mathrm{L}^{-1}\right.$ was the maximum soluble concentration) and subjected to a probit analysis. The mortality at the highest concentration of fenvalerate assayed was $38.5 \%$ in $2002,42.3 \%$ in 2005 and $21 \%$ in 2008 . These results indicated a small increase in the susceptibility to fenvalerate in the FO population collected in 2005 relative to 2002 , followed by a decreased susceptibility in 2008; because a probit analysis could not be performed, the significance of this value is unknown. The $\mathrm{LC}_{50}$ and slope value for the field-reference population (PA) recorded in 2005 were $0.0045 \mathrm{mg} \mathrm{L}^{-1}$ and 3.1, respectively. Considering the entire monitoring period, including the previously published results from 1997 and 1999 (Montagna et al. 1999, 2003), a significant increase in fenvalerate resistance was observed in the FO population from 1997-2008. Three stages in the process of resistance development were apparent. At first, the $\mathrm{LC}_{50}$ values increased significantly from $0.15 \mathrm{mg} \mathrm{L}^{-1}$ in 1997 to $0.76 \mathrm{mg} \mathrm{L}^{-1}$ in 1999 (Table) and to even higher values in 2002, according to the probit analysis (Fig. 1). The resistance ratios at the $\mathrm{LC}_{50}$ level were 88 and 395 in 1997 and 1999, respectively (Table). During this stage, a shallow slope (1.4) was followed by a steep slope (3.2), suggesting an increase in homogeneity. Subsequently, there was a small initial increase in the susceptibility to fenvalerate in 2005 and a decrease in 2008 .

The concentration mortality lines for deltamethrin are shown in Fig. 2 with complementary results from 1997 that have been published elsewhere (Montagna et al. 1999). The $\mathrm{LC}_{50}\left(\mathrm{mg} \mathrm{L}^{-1}\right)$ and slope values (in parentheses) for deltamethrin for the FO population were 0.010 (4.5), 0.0052 (2.5) and 0.0065 (1.3) in 1999, 2002 and 2008, respectively. The $\mathrm{LC}_{50}$ value for the field-reference population collected in 1999 was $4.0 \times 10^{-5} \mathrm{mg} \mathrm{L}^{-1}$. The resistance ratios at the $\mathrm{LC}_{50}$ level were 250,130 and 162 for the sampling periods of 1999, 2002 and 2008, respectively. Considering the entire monitoring period, including the previously published results from 1997 (Montagna et al. 1999), the trend of deltamethrin resistance was quite similar to that observed for fenvalerate in the $\mathrm{FO}$ population (Figs 1, 2). The $\mathrm{LC}_{50}$

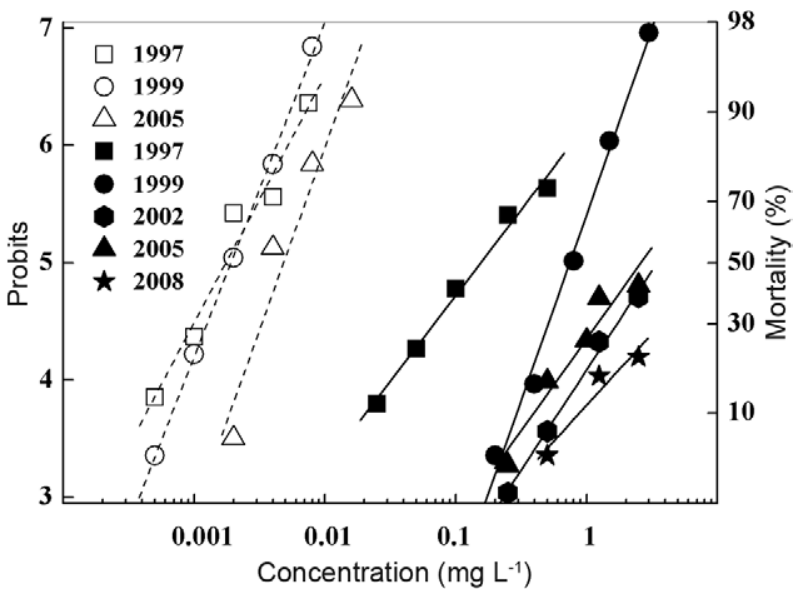

Fig. 1: concentration-mortality regression lines for fenvalerate against field-reference (open symbol) and resistant (solid symbol) larvae of black flies from the sampled years. Data of collection in 1997 and 1999 are from Montagna et al. (1999, 2003), respectively.

values significantly increased from $0.0027 \mathrm{mg} \mathrm{L}^{-1}$ in 1997 to $0.010 \mathrm{mg} \mathrm{L}^{-1}$ in 1999 and the slopes of the regression lines were shallow (2.0) and steep (4.5) in these two years, respectively (Table), suggesting an increase in the homogeneity towards resistance. The FO population was 90 and 250-fold more resistant at the $\mathrm{LC}_{50}$ level than the PA populations collected in 1997 and 1999, respectively. Subsequently, there was a non-significant decline in the $\mathrm{LC}_{50}$ value between 1999-2002, according to the CIs. Finally, there was a small increase in the $\mathrm{LC}_{50}$ value in 2008 that was significantly different from that in 1999, but not that in 2002. The $\mathrm{LC}_{50}$ values recorded for the field-reference population (PA) were $3.0 \times 10^{-5} \mathrm{mg} \mathrm{L}^{-1}$ in 1997 and $4.0 \times$ $10^{-5} \mathrm{mg} \mathrm{L}^{-1}$ in 1999; the differences were not significant.

The concentration mortality lines for azinphos methyl are shown in Fig. 3 with complementary results from the sampling periods of 1996 (Montagna et al. 1999) and 2005 (Anguiano et al. 2008). The $\mathrm{LC}_{50}\left(\mathrm{mg} \mathrm{L}^{-1}\right)$ and slope values (in parentheses) recorded for the FO population for azinphos methyl were 0.024 (4.7) and 0.042 (6.4) in 2000. In contrast, the $\mathrm{LC}_{50}$ value for the field-reference population was $0.0090 \mathrm{mg} \mathrm{L}^{-1}$ in 2000 , which, according to the CI, was significantly different from that of the resistant population. The resistance ratios at the $\mathrm{LC}_{50}$ level were 2.7 and 4.6 for the sampling periods of 2002 and 2008 , respectively. Collectively, the new results and the previously published results from 1996 and 2005 (Montagna et al. 1999, Anguiano et al. 2008) indicate that the FO population exhibited a small but significant increase in azinphos methyl resistance from 1996-2002 compared with the field-reference population. The resistance ratios at the $\mathrm{LC}_{50}$ values were 1.7, 2.7 and 4.6 in 1996, 2000 and 2002 , respectively. Conversely, the FO population exhibited a significant increase in the susceptibility to azinphos methyl from $2002\left(0.042 \mathrm{mg} \mathrm{L}^{-1}\right)$ to $2005\left(\mathrm{LC}_{50}=0.021\right.$ $\mathrm{mg} \mathrm{L}^{-1}$ ). In contrast to the response of the larvae from FO to pyrethroids, small changes in the regression slopes for azinphos methyl were observed during the sampling pe- 
TABLE

Comparative toxicity of several insecticides to resistant Fernández Oro (FO) and field-reference Piedra del Águila (PA) larvae of Simulium spp of those bioassays where data were complete for probit analysis

\begin{tabular}{|c|c|c|c|c|c|c|c|}
\hline Insecticide & $\begin{array}{c}\text { Population } \\
\text { (year of collection) }\end{array}$ & $\mathrm{n}$ & Slope \pm SE & $\begin{array}{c}\mathrm{LC}_{50}(95 \% \mathrm{CI}) \\
(\mathrm{mg} / \mathrm{L})\end{array}$ & $\mathrm{LC}_{95}(95 \% \mathrm{CI})$ & $\chi^{2}$ & $\mathrm{R} / \mathrm{S}$ \\
\hline \multirow[t]{5}{*}{ Fenvalerate } & PA $\left(1997^{a}\right)$ & 480 & $2.1 \pm 0.19$ & $0.0017(0.0015-0.0020)$ & $0.011(0.0079-0.016)$ & 6.66 & - \\
\hline & PA $\left(1999^{b}\right)$ & 359 & $2.8 \pm 0.26$ & $0.0019(0.0017-0.0022)$ & $0.0074(0.0058-0.010)$ & 0.17 & - \\
\hline & PA (2005) & 300 & $3.1 \pm 0.95$ & $0.0045(0.00021-0.091)$ & $0.015(0.00003-17)$ & 5.8 & - \\
\hline & FO $\left(1997^{a}\right)$ & 419 & $1.4 \pm 0.17$ & $0.15(0.12-0.19)$ & $2.05(1.17-4.91)$ & 1.04 & 88.23 \\
\hline & FO $\left(1999^{b}\right)$ & 399 & $3.2 \pm 0.26$ & $0.76(0.68-0.86)$ & $2.45(2.02-3.14)$ & 2.07 & 400 \\
\hline \multirow[t]{6}{*}{ Deltamethrin } & PA $\left(1997^{a}\right)$ & 299 & $3.8 \pm 0.78$ & $0.000030(0.000003-0.00028)$ & $0.000082(0.000001-0.0003)$ & 1.1 & - \\
\hline & PA (1999) & 360 & $4.6 \pm 0.50$ & $0.000040(0.000036-0.000044)$ & $0.000091(0.00008-0.00011)$ & 0.75 & - \\
\hline & FO $\left(1997^{a}\right)$ & 560 & $2.0 \pm 0.14$ & $0.0027(0.0023-0.0032)$ & $0.018(0.014-0.025)$ & 3.67 & 90 \\
\hline & FO (1999) & 400 & $4.5 \pm 0.40$ & $0.010(0.0096-0.0111)$ & $0.024(0.021-0.029)$ & 4.61 & 250 \\
\hline & FO (2002) & 360 & $2.5 \pm 0.29$ & $0.0052(0.0044-0.0060)$ & $0.023(0.017-0.035)$ & 5.68 & $130^{c}$ \\
\hline & FO (2008) & 279 & $1.3 \pm 0.59$ & $0.0065(0.0058-0.0072)$ & $0.015(0.012-0.017)$ & 0.014 & $162^{c}$ \\
\hline \multirow[t]{7}{*}{ Azinphos methyl } & PA $\left(1996^{a}\right)$ & 300 & $4.9 \pm 0.51$ & $0.0068(0.0062-0.0075)$ & $0.015(0.012-0.019)$ & 3.81 & - \\
\hline & PA (2000) & 300 & $8.7 \pm 0.97$ & $0.0090(0.0085-0.0096)$ & $0.014(0.013-0.016)$ & 0.64 & - \\
\hline & PA (2005) & 240 & $5.6 \pm 0.68$ & $0.011(0.010-0.012)$ & $0.022(0.018-0.029)$ & 1.13 & - \\
\hline & $\mathrm{FO}\left(1996^{a}\right)$ & 360 & $7.8 \pm 0.72$ & $0.012(0.011-0.013)$ & $0.020(0.018-0.022)$ & 1.15 & 1.7 \\
\hline & FO (2000) & 300 & $4.7 \pm 0.64$ & $0.024(0.022-0.027)$ & $0.054(0.043-0.078)$ & 1.33 & 2.6 \\
\hline & FO (2002) & 299 & $6.4 \pm 0.70$ & $0.042(0.038-0.045)$ & $0.075(0.066-0.090)$ & 1.57 & $4.6^{d}$ \\
\hline & FO (2005) & 239 & $5.87 \pm 0.87$ & $0.021(0.019-0.022)$ & $0.40(0.34-0.53)$ & 1.74 & 1.9 \\
\hline
\end{tabular}

$a$ : from Montagna et al. (1999); $b$ : from Montagna et al. (2003); $c$ : resistance ratios were calculated using the $\mathrm{LC}_{50}$ of the fieldreference population from 1999; $d$ : resistance ratios were calculated using the $\mathrm{LC}_{50}$ of the field-reference population from 2000 ; $\mathrm{CI}$ : confidence interval; R/S: resistance ratios [lethal concentration fifty $\left(\mathrm{LC}_{50}\right)$ of the resistant population/LC $\mathrm{L}_{50}$ of the fieldreference population]; SE: standard error.

riod. The $\mathrm{LC}_{50}$ values for the field-reference population (PA) ranged from $0.0068 \mathrm{mg} \mathrm{L}^{-1}$ in 1996 to $0.011 \mathrm{mg} \mathrm{L}^{-1}$ in 2005. There were no significant differences between the $\mathrm{LC}_{50}$ values calculated in 1996 and 2000. However, according to the confidence limits, there was a significant increase in the $\mathrm{LC}_{50}$ in 2005 relative to 1996 and 2000.

Enzyme activity - The general esterase activity from individual larvae in the resistant and field-reference populations, along with complementary results from the sampling periods of 1999 and 2005 that have been published elsewhere (Montagna et al. 2003, Anguiano et al. 2008), are illustrated in box-and-whisker plots in Fig. 4. The mean esterase activity \pm standard deviation (SD) $\left(\mu \mathrm{g} \mathrm{min}^{-1} \mathrm{mg}^{-1}\right)$ of the FO population in $2009(2.85 \pm 1.51)$ was significantly higher $(\mathrm{p}<0.05)$ than that of the PA population in $2005(0.86 \pm 0.35)$ (Anguiano et al. 2008).

Considering the entire monitoring period, including the previously published results from 1999 and 2005 (Montagna et al. 1999, Anguiano et al. 2008), the average esterase activity in the resistant population consistently increased throughout the sampling period, although the differences between $2005\left(2.17 \pm 1.71 \mu \mathrm{g} \mathrm{min}^{-1} \mathrm{mg}^{-1}\right)$ and 2009 were not statistically significant. The mean activities in $1999\left(1.29 \pm 1.13 \mu \mathrm{g} \mathrm{min}^{-1} \mathrm{mg}^{-1}\right)$ and 2005 may be overestimated as a result of a few very high values. Indeed, the distribution of esterase activities of the FO population collected in 2009 exhibited a much smaller departure from normality (skewness $=0.72$ ) than those measured in 1999 (skewness $=3.62$ ) and 2005 (skew- ness $=3.31)$. The mean $\pm \mathrm{SD}$ esterase activities $\left(\mu \mathrm{g} \mathrm{min}^{-1}\right.$ $\left.\mathrm{mg}^{-1}\right)$ in the field-reference population were $0.46 \pm 0.25$ in 1999 and $0.86 \pm 0.35$ in 2005 and the differences were not significant. The frequency of individuals from the resistant population with esterase activities higher than the maximum value observed in the PA population were $9.6 \%$ in $1999,29.7 \%$ in 2005 and $55.8 \%$ in 2009.

The GST activities recorded from both populations in the present study and in a previous study (Montagna et al. 2003) are shown in Fig. 5 as box-and-whisker plots. The mean \pm SD enzyme activity recorded for the field-reference population in $2005(0.20 \pm 0.0178 \mu$ moles CDNB $\min ^{-1} \mathrm{mg}$ protein $\left.{ }^{-1}\right)$ was significantly lower $(\mathrm{p}=0.011)$ than that determined in the resistant population during the same sampling period $(0.23 \pm 0.026 \mu$ moles CDNB $\min ^{-1} \mathrm{mg}$ protein $\left.{ }^{-1}\right)$. Conversely, the mean $\pm \mathrm{SD}$ enzyme activity determined for the field-reference population in 2005 was not significantly different $(p=0.76)$ from that recorded for the resistant population in $2009(0.19 \pm 0.021$ $\mu$ moles CDNB $\min ^{-1} \mathrm{mg}$ protein $\left.{ }^{-1}\right)$. Unexpectedly, the mean GST activity of the FO population in 2009 was significantly lower $(\mathrm{p}=0.005)$ than that of the 2005 collection. Moreover, the distribution of this enzyme activity in the FO population collected in 2009 exhibited a much smaller departure from normality (skewness $=1.47$ ) than the population collected in 2005 (skewness $=-3.05$ ). Finally, both the previous (Montagna et al. 2003) and the present results demonstrated that the GST activities of the resistant population fluctuated over the years. 


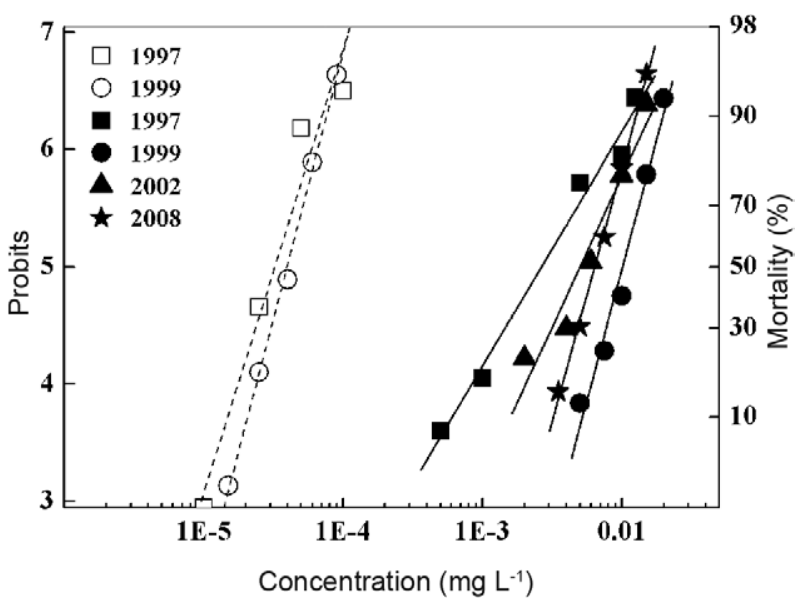

Fig. 2: concentration-mortality regression lines for deltamethrin against field-reference (open symbol) and resistant (solid symbol) larvae of black flies from the sampled years. Data of collection in 1997 and 1999 are from Montagna et al. $(1999,2003)$, respectively.

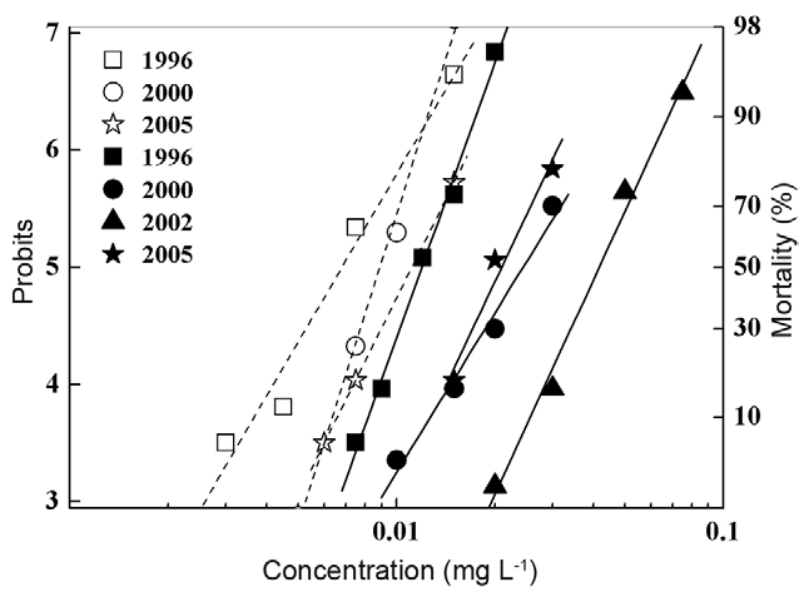

Fig. 3: concentration-mortality regression lines for azinphos methyl against field-reference (open symbol) and resistant (solid symbol) larvae of black flies from the sampled years. Data of collection in 1996 and 2005 are from Montagna et al. $(1999,2003)$, respectively.

\section{DISCUSSION}

Adaptive evolutionary changes that occur within decades or less are defined as contemporary evolution. The development of resistance in response to intensive pesticide pressure is an example of this adaptive continuous evolution (Stockwell et al. 2003). The frequency of resistant genotypes increases in populations under insecticide pressure and the regression lines shift to the right with lower slope values (Brown \& Pal 1971). As the selection pressure continues, increased $\mathrm{LC}_{50}$ and $\mathrm{LC}_{95}$ values associated with higher slopes are indicative of the progression of resistance to a higher intensity and frequency of resistant genotypes (Norris 1957, Immaraju et al. 1989). A subsequent decrease in the slope value would be indicative of an evolution of resistance to higher intensities (Immaraju et al. 1989). Increased $\mathrm{LC}_{50}$ values and slope

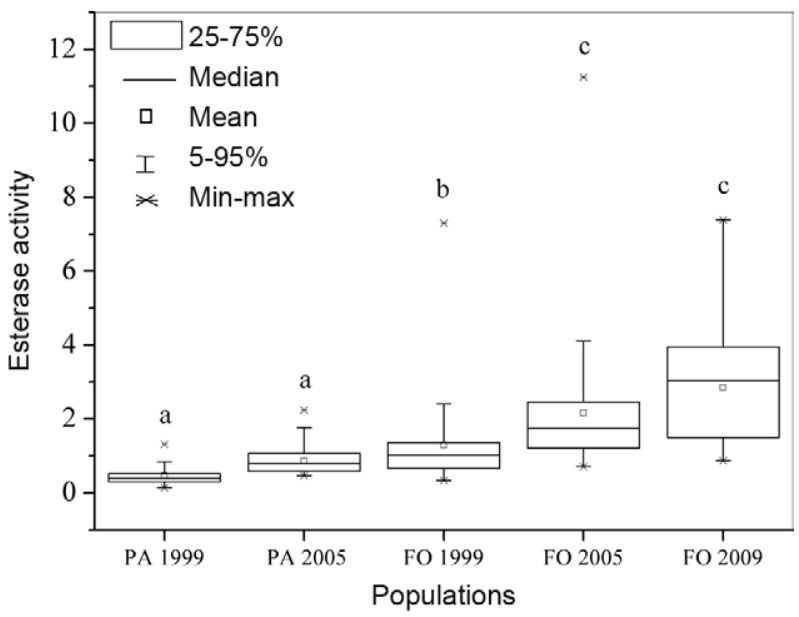

Fig. 4: trend of esterase activities ( $\mu \mathrm{mol} \alpha$-naphthol $\mathrm{min}^{-1} \mathrm{mg}^{-1}$ protein) from individual larvae of field-reference (1999: $\mathrm{n}=96 ; 2005: \mathrm{n}=80$ ) and resistant populations (1999: $n=94 ; 2005: n=90 ; 2009: n=43$ ) of black flies. Means followed by the same letters were not statistically different according to Dunn's multiple comparison test. Data of collection in 1999 and 2005 are from Montagna et al. (2003) and Anguiano et al. (2008), respectively. FO: Fernández Oro; PA: Piedra del Águila.

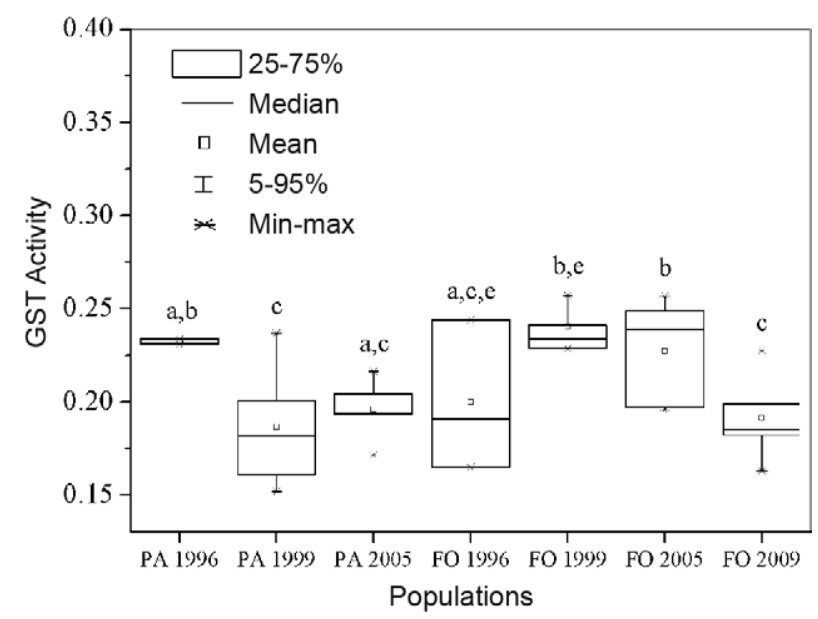

Fig. 5: trend of glutathione S-transferase (GST) activities ( $\mu$ mol 1-chloro-2,4-dinitrobenzene $\mathrm{min}^{-1} \mathrm{mg}^{-1}$ protein) from batches of 25 larvae of field-reference (1996: $\mathrm{n}=4 ; 1999: \mathrm{n}=5 ; 2005: \mathrm{n}=5)$ and resistant populations $(1996: \mathrm{n}=4 ; 1999: \mathrm{n}=4 ; 2005: \mathrm{n}=5 ; 2009: \mathrm{n}=$ 6) of black flies. Means followed by the same letters were not statistically different according to Fisher least significant difference test. Data of collection in 1996 and 1999 are from Montagna et al. (2003). FO: Fernández Oro; PA: Piedra del Águila.

changes have already been observed under laboratory and field insecticide selection in both insect (Georghiou et al. 1966, Georghiou \& Hawley 1971, Sarkar et al. 2009) and mite populations (Sato et al. 2000).

The contemporary evolution of pesticide resistance in a field population is a complex, stepwise process influenced by genetic, biological/ecological and operational factors. Some genetic factors that contribute to the rapid development of resistance are the dominance, ini- 
tial frequency and number of $R$ alleles and the integration of $R$ alleles with fitness factors. A high reproduction potential of the species associated with low mobility and a lack of untreated reservoirs are some of the biologi$\mathrm{cal} /$ ecological factors that accelerate the evolution of resistance. The operational factors are related to both the chemicals and the application procedures. Among these factors, the development of resistance is favoured if the pesticide is persistent in the environment, the application rate is high and frequent, there is no chemical rotation and the insecticide pressure occurs in more than one life stage (Georghiou \& Taylor 1986).

The rapid evolution of resistance to pyrethroids, principally fenvalerate, in black flies from FO observed in both the present and previous studies (Montagna et al. 1999, 2003) may be explained by both the nature of the FO population and the control strategies used against the codling moth. Among black flies from the study area, the following factors may be related to a high insecticide selection pressure. First, black flies have at least three generations per year and their life cycle overlaps with pesticide applications. In the laboratory, a shorter life cycle results in the faster development of insecticide resistance (Kočišová et al. 1995). Second, there is no refuge for larvae; they remain in the same location for the entire larval stage and are unable to escape from pesticide applications that reach the irrigation channels by air drift and natural run-off. Groeters and Tabashnik (2000) concluded from simulation models that the delay of resistance increases as the refuge size increases. Third, black fly larvae feed on filtered particulate matter, in which pesticide accumulation and persistence are greater than in water. Wauchope (1978) and Schulz (2001) observed higher levels of organochlorine, organophosphate and pyrethroid insecticides in the suspended particles than in the water. Finally, adult black flies from FO may also be under insecticide pressure either during insecticide application or during rest through absorption of the chemical from fruit leaves. Regarding the operational factors involved in the rapid evolution of pyrethroid resistance during the first years of sampling, this family of insecticides (fenvalerate, deltamethrin, cypermethrin and lambda-cyhalothrin, among others) was introduced in 1982 and used extensively for almost two decades. Furthermore, traditional pest control programmes usually included in up to 10 applications of insecticides each growing season. Pyrethroids were subsequently restricted in the valley because they failed to control C. pomonella. Instead, azinphos methyl was principally recommended for pest management. Since 2005, acetamiprid, rynaxypyr, spinosad and other unconventional pesticides have been the main insecticides of choice and there are only a few applications of pyrethroids and azinphos methyl during each growing season. Modifications in the pesticide applications during recent years of sampling may explain the slight evolution of fenvalerate and deltamethrin resistance over this period. The shallow slope of the regression line of fenvalerate observed in the FO population in 2008 suggests a vast potential for the enhancement of the resistance levels. The resistance to azinphos methyl increased until 2002, with a subsequent reversion in 2005.
Previous work (Montagna et al. 2003) has suggested that target insensitivity and enzyme detoxification are involved in pyrethroid resistance. The use of the synergists piperonyl butoxide and S,S,S-tributyl phosphorotrithioate (DEF) has confirmed the primary contribution of oxidases and esterases to pyrethroid resistance. In the present study, the resistant population exhibited 2.5 (2005 collection) and 3.3-fold (2009 collection) higher mean esterase activities than the field-reference population in 2005. These and previous (Montagna et al. 2003) results indicate the involvement of these enzymes in pyrethroid resistance. Conversely, the mean GST activity of the resistant population collected in 2005 was only 1.15 -fold higher than that of the field-reference population in the same collection year. Moreover, there were no significant differences between the mean GST activities of the resistant and the field-reference populations between 20092005 , respectively. Taking into account previous results (Montagna et al. 2003), the mean GST activities in the resistant population were lower (1.15-fold) and higher (1.26-fold) than the field-reference population in 1996 and 1999, respectively; thus, the role of these enzymes in pyrethroid resistance in the FO population is negligible.

The enhanced GST activities observed in the FO populations collected in 1999 and 2005 and the subsequent decrease in 2009 may be associated with both the frequent and occasional use of azinphos methyl.

Pyrethroid resistance has been associated with increased GST and mixed function oxidase activities (Djouaka et al. 2011, Strong et al. 2008, Morgan et al. 2010) or GST and esterase activities (Munhenga et al. 2008) in mosquitoes. In contrast, increased GST activity has been associated with azinphos methyl resistance in two lepidopteran species (Suckling et al. 1990, FuentesContreras et al. 2007). In black flies, higher levels of esterase activity (Magnin et al. 1987, Andrade \& Branco 1990, Parker \& Callaghan 1997) have been identified in organophosphate-resistant populations.

Recent studies suggest that esterases provide a mechanism of resistance that is reselected by the pesticides currently used to control fruit tree pests. Although mixed function oxidases are involved in the principal resistance mechanism against acetamiprid in Apis mellifera and spinosad in Spodoptera exigua, a significant synergism effect of DEF on both pesticides has also been demonstrated (Iwasa et al. 2004, Wang et al. 2006).

The present results showed that resistance to pyrethroids in the FO population has evolved very rapidly during the period in which these pesticides were extensively applied to control $C$. pomonella and other fruit pests. Following the introduction of unconventional pesticides, fenvalerate and deltamethrin resistance reached a relatively steady state and subsequently increased. The levels of resistance to azinphos methyl were low over the survey period, regardless of the massive use of this pesticide over a five-year period. Esterase activity is involved in one of the mechanisms underlying the high levels of pyrethroid resistance in black flies. These enzymes may be reselected by currently used pesticides and the increased activity of these enzymes enhances the pyrethroid resistance that has been observed recently. 
In response to increasing populations of black flies, the government of Argentina initiated a pilot programme in 1991 to evaluate the effectiveness of larval control in irrigation channels and drainage ditches with $B$. thuringiensis israelensis (Vectobac AS). Although most trials resulted in effective larval mortality, the projected cost of the black fly suppression programme in the Río Negro Valley with this method was very expensive (Gray et al. 1999). To efficiently decrease black fly populations in this area at a lower cost than biological control alone, an array of strategies should be implemented. First, the breeding sites must be decreased by the systematic and mechanical removal of channel vegetation, which serves as a substrate for the immature stages. Second, the black fly population densities must be monitored so that treatment with $B$. thuringiensis toxins can be administered at the peak density. Finally, both the fruit-pest and black fly chemical controls must be coordinated. In agreement with the final recommendation, further studies will focus on the evaluation of black fly sensitivity to more selective insecticides, such as neonicotinoids and the insect growth regulators that are currently in use.

\section{ACKNOWLEDGEMENTS}

To Guillermo Sabino, Department of Statistic, Facultad de Economía y Administración, for the suggestion in the statistical analysis.

\section{REFERENCES}

Andrade CFS, Branco Jr AC 1990. Methods for field detection of resistance to temephos in simuliids. Larval esterase level and topical application of the insecticide to adults. Mem Inst Oswaldo Cruz 85: 291-297.

Anguiano O, Ferrari A, Soleño J, Martinez M, Pechen de D'Angelo AM, Venturino A, Montagna C 2008. Enhanced esterase activity and resistance to azinphosmethyl in target and non-target organisms. Environ Toxicol Chem 27: 2117-2123.

Bartninkaitė I, Bernotienė R, Pakalniŝkis S, Žygutienė M 2006. Control of bloodsucking black fly (Simuliidae) populations in Lithuania. Ekologija 4: 70-75.

Brown AWA, Pal K 1971. The nature and characterization of resistance. In AWA Brown, $\mathrm{K} \mathrm{Pal}$, Insecticide resistance in arthropods, Monograph Series 38, World Health Organization, Geneva, p. 9-44.

Coscarón S 1997. Estudio bioecológico de simulidos (jejenes) en las Provincias de Neuquén y Río Negro para la determinación de métodos de control racional. Autoridad Interjurisdiccional de las Cuencas de los Ríos Limay, Neuquén y Negro y Fundación de la Universidad Nacional del Comahue para el desarrollo regional, Technical Report, Buenos Aires, 147 pp.

Crosskey RW, Howard TM 2004. A revised taxonomic and geographical inventory of world blackflies (Diptera: Simuliidae). Available from: nhm.ac.uk/research-curation/projects/ blackflies.

Currie DC, Adler PH 2008. Global diversity of black flies (Diptera: Simuliidae) in freshwater. Hydrobiologia 595: 469-475.

Dary O, Georghiou GP, Parsons E, Pasteur N 1990. Microplate adaptation of Gomori's assay for quantitative determination of general esterase activity in single insects. $J$ Econ Entomol 83: 2187-2192.

De Villiers PC 1987. Simulium dermatitis in man-clinical and biological features in South Africa. S Afr Med J 71: 523-525.

Diabate A, Baldet T, Chandre F, Akogbeto M, Guiguemde TR, Darriet F, Brengues C, Guillet P, Hemingway J, Small GJ, Hougard
JM 2002. The role of agricultural use of insecticides in resistance to pyrethroids in Anopheles gambiae S.L. in Burkina Faso. Am J Trop Med Hyg 67: 617-622.

Djouaka R, Irving H, Tukur Z, Wondji CS 2011. Exploring mechanisms of multiple insecticide resistance in a population of the malaria vector Anopheles funestus in Benin. PLoS ONE 6: e27760.

Etya'ale DE 2001. Vision 2020: Update on onchocerciasis. J Comm Eye Health 14: 19-21.

Fuentes-Contreras E, Reyes M, Barros W, Sauphanor B 2007. Evaluation of azinphos-methyl resistance and activity of detoxifying enzymes in codling moth Lepidoptera: Tortricidae) from central Chile. J Econ Entomol 100: 551-556.

Georghiou GP, Hawley MK 1971. Insecticide resistance resulting from sequential selection of houseflies in the field by organophosphorus compounds. Bull World Health Organ 45: 43-51.

Georghiou GP, Metcalf IR, Gidden FE 1966. Carbamate-resistance in mosquitos. Bull World Health Organ 35: 691-708.

Georghiou GP, Taylor CE 1986. Factors influencing the evolution of resistance. In Pesticide resistance: strategies and tactics for management, National Academy Press, Washington DC, p. 157-169.

Gray EW, Adler PH, Coscarón-Arias C, Coscarón S, Noblet R 1999. Development of the first black fly (Diptera: Simuliidae) management program in Argentina and comparison with other programs. J Am Mosq Control Assoc 15: 400-406.

Groeters FR, Tabashnik BE 2000. Roles of selection intensity, mayor genes and minor genes in evolution of insecticide resistance. J Econ Entomol 9: 1580-1587.

Habig WH, Pabst MJ, Jacoby WB 1974. Glutathione S-transferases. The first enzymatic step in mercapturic acid formation. $J$ Biol Chem 249: 7130-7139.

Hougard JM, Escaffre H, Darriet F, Lochouarn L, Rivière F, Back C 1992. An episode of resistance to permethrin in larvae of Simulium squamosum (Diptera: Simuliidae) from Cameroon, after 31/2 years of control. J Am Mosq Control Assoc 8: 184-186.

Immaraju JA, Morse JG, Kersten DJ 1989. Citrus trips (Thysanoptera: Thripidae) pesticide resistance in the Coachella and San Joaquin Valleys of California. J Econ Entomol 82: 374-380.

Iwasa T, Motoyama N, Ambrose JT, Roe RM 2004. Mechanism for the differential toxicity of neonicotinoid insecticides in the honey bee, Apis mellifera. Crop Protect 23: 371-378.

Kočišová A, Kukučka D, Petrovský M, Para L 1995. The development of resistance in the house fly (Musca domestica) and the German cockroach (Blatella germanica) alter the selection with permethrin. Folia Vet 39: 49-51.

Lowry OH, Rosebroung NJ, Farr AL, Randall RJ 1951. Protein measurement with the Update on onchocerciasis phenol reagent. J Biol Chem 193: 265-275.

Magnin M, Kurtak D, Pasteur N 1987. Caractérisation des estérases chez des larves du complexe Simulium damnosum résistantes aux insecticides organophosphorus. Cahiers ORSTOM Ser Entomol Med Parasitol 25: 57-62.

McMahon JP 1967. A review of the control of Simulium vectors of onchocerciasis. Bull World Health Organ 37: 415-430.

Montagna CM, Anguiano OL, Gauna LE, Pechen de D'Angelo AM 1999. Resistance to pyrethroids and DDT in a field-mixed population of Argentinean black flies (Diptera: Simuliidae). J Econ Entomol 92: 1243-1245.

Montagna CM, Anguiano OL, Gauna LE, Pechen de D’Angelo AM 2003. Mechanisms of resistance to DDT and pyrethroids in Patagonian populations of Simulium black flies. Med Vet Entomol 17: 95-101. 
Morgan JC, Irving H, Okedi LM, Steven A, Wondji CS 2010. Pyrethroid resistance in an Anopheles funestus population from Uganda. PLOS ONE 5: e11872.

Munhenga G, Masendu HT, Brooke BD, Hunt RH, Koekemoer LK 2008. Pyrethroid resistance in the major malaria vector Anopheles arabiensis from Gwave, a malaria-endemic area in Zimbabwe. Malar J 28: 247.

Norris DM 1957. The nature and development of insect resistance to insecticides. Fla State Hor Soc: 144-146.

Osei-Atweneboana MY, Wilson MD, Post RJ, Boakye DA 2001. Temephos-resistant larvae of Simulium sanctipauli associated with a distinctive new chromosome inversion in untreated rivers of South-Western Ghana. Med Vet Entomol 15: 113-116.

Parker PJA, Callaghan A 1997. Esterase activity and allele frequency in field populations of Simulium equinum (L.) (Diptera: Simuliidae) exposed to organophosphate pollution. Environ Toxicol Chem 16: 2550-2555.

Paugy D, Fermon Y, Abban KE, Diop ME, Traoré K 1999. Onchocerciasis control programme in West Africa: a 20-year monitoring of fish assemblages. Aquat Living Resour 12: 363-378.

Raymond M 1985. Présentation d'un programme d'analyse log-probit pour micro-ordinateur. Cahiers ORSTOM Ser Entomol Med Parasitol 22: 117-121.

Regis L, da Silva SB, Melo-Santos MAV 2000. The use of bacterial larvicides in mosquito and black fly control programmes in Brazil. Mem Inst Oswaldo Cruz 95 (Suppl. I): 207-210.

Rivers-Moore NA, Bangay S, Palmer RW 2008. Optimisation of $B a-$ cillus thuringiensis var. israelensis $\left(\right.$ Vectobac $\left.^{\mathbb{E}}\right)$ applications for the blackfly control programme on the Orange River, South Africa. Water SA 34: 193-198.

Ruas Neto AL 1984. Avaliação do uso de temephos para o controle de culicídos e simulídeos no Rio Grande do Sul. Bol Saude 11: 27-31.

Sarkar M, Bhattacharyya IK, Borkotoki A, Baruah I, Srivastava RB 2009. Development of physiological resistance and its stage specificity in Culex quinquefasciatus after selection with deltamethrin in Assam, India. Mem Inst Oswaldo Cruz 104: 673-677.
Sato ME, Miyata T, Kawai A, Nakano O 2000. Selection for resistance and susceptibility and cross resistance in Amblyseius womersleyi Schicha (Acari: Pytoseiidae). App Entomol Zool 35: 393-399.

Schmidtmann ET, Lloyd JE, Bobian RJ, Kumar R, Waggoner Jr JW, Tabachnick WJ, Legg D 2001. Suppression of mosquito (Diptera: Culicidae) and black fly (Diptera: Simuliidae) blood feeding from Hereford cattle and ponies treated with permethrin. $J$ Med Entoml 38: 728-734.

Schulz R 2001. Rainfall-induced sediment and pesticide input from orchards into the Lourens River, Western Cape, South Africa: importance of a single event. Water Resour 35: 1869-1876.

Shelley AJ 2002. Human onchocerciasis in Brazil: an overview. Cad Saude Publica 18: 1167-1177.

Stockwell CA, Hendry AP, Kinnison MT 2003. Contemporary evolution meets conservation biology. Trends Ecol Evol 18: 94-101.

Strong AC, Kondratieff BC, Doyle MS, Black WC 2008. Resistance to permethrin in Culex tarsalis in northeastern Colorado. Am Mosq Control Assoc 24: 281-288.

Suckling DM, Armstrong KF, Khoo JGI 1990. Selection with azinphosmethyl influences glutathione S-transferase activity in the light brown apple moth, Epiphyas postvittana (Lepidoptera: Tortricidae). Pestic Biochem Physiol 38: 9-17.

Wang W, Mo J, Cheng J, Zhuang P, Tang Z 2006. Selection and characterization of spinosad resistance in Spodoptera exigua (Hübner) (Lepidoptera: Noctuidae). Pest Biochem Physiol 84: 180-186.

Wauchope RD 1978. The pesticide content of surface water draining from agricultural fields. A review. J Environ Qual 7: 459-472.

Williams T 1991. The ubiquitous occurrence of Simulium posticatum (Diptera) in rivers around Oxford. Entomologist 11: 33-36.

Yamagata Y, Ochoa JO, Molina PA, Sato H, Uemoto K, Suzuki T 1987. Chemical control of Simulium ochraceum Walker (Diptera: Simuliidae) larvae in an onchocerciasis endemic area of Guatemala. Trop Med Parasitol 38: 205-210.

Youssefi MR, Aminpour A, Arabkhazaeli F 2008. Dermatitis caused by Simulium (black fly) bite. Iranian J Parasitol 3: 48-45. 